\title{
PEMETAAN KARAKTERISTIK WILAYAH URBAN DAN RURAL DI WILAYAH BANDUNG RAYA DENGAN METODE SPATIAL CLUSTERING
}

\author{
Riya Supriyatin ${ }^{1}$, Andrea Emma Pravitasari ${ }^{2}$, Didit Okta Pribadi ${ }^{3}$ \\ 1Progam Studi Ilmu Perencanaan Wilayah, Sekolah Pascasarjana, Institut Pertanian Bogor \\ Jl. Meranti, Kampus IPB Dramaga, Bogor, Jawa Barat 16680, Indonesia \\ 2Departemen Ilmu Tanah dan Sumberdaya Lahan, Institut Pertanian Bogor \\ Jalan Meranti, Kampus IPB Dramaga, Bogor Jawa Barat 16680, Indonesia \\ 2Pusat Pengkajian Perencanaan dan Pengembangan Wilayah (P4W) LPPM \\ Institut Pertanian Bogor, Kampus IPB Baranangsiang, \\ Jalan Raya Pajajaran, Bogor 16127, Indonesia \\ ${ }^{3}$ Balai Konservasi Tumbuhan Kebun Raya Bogor, LIPI \\ Jalan Ir H Juanda No 13, Bogor Tengah, Bogor, Jawa Barat, 16122, Indonesia \\ e-mail: riya_supriyatin@yahoo.com
}

Diterima: 28 Maret 2020, Direvisi: 22 April 2020, Disetujui: 06 Juni 2020

\begin{abstract}
Abstrak
Perkembangan wilayah suatu daerah yang terus meningkat baik dari segi sosial maupun ekonomi menarik minat penduduk wilayah lain untuk berkegiatan di daerah tersebut. Perkembangan wilayah dapat dipengaruhi oleh berbagai faktor baik faktor fisik maupun non fisik. Penelitian ini bertujuan untuk mengelompokkan dan memetakan karakteristik wilayah urban dan rural di wilayah Bandung Raya berdasarkan tipologi perkembangan wilayah di masing-masing kecamatan. Sehingga pembangunan yang direncanakan dapat efektif dan efisien sesuai kondisi di masing-masing kecamatan. Penelitian ini menggunakan data sekunder yang diperoleh dari berbagai instansi. Variabel yang digunakan antara lain indeks ketersediaan fasilitas ekonomi, indeks ketersediaan fasilitas sosial, indeks ketersediaan fasilitas pendidikan, rasio lahan terbangun, densitas jaringan jalan dan kepadatan penduduk dengan unit penelitian berjumlah 106 kecamatan. Data dianalisis menggunakan metode Skalogram Dimodifikasi, Principal Component Analisis dan Spatial Clustering. Hasil analisis menunjukkan berdasarkan tipologi perkembangan wilayah, Bandung Raya dikelompokan menjadi 3 cluster yaitu urban (perkotaan), suburban dan rural (perdesaan). Cluster perkotaan terdiri atas 34 kecamatan menyebar di Kota Bandung dan Kota Cimahi. Cluster suburban terdiri atas 43 kecamatan menyebar di Kabupaten Bandung Barat dan Kabupaten Bandung. Cluster perdesaan terdiri atas 29 kecamatan menyebar di Kabupaten Sumedang
\end{abstract}

Kata kunci: fasilitas, lahan terbangun, perkembangan wilayah, Skalogram Dimodifikasi, Spatial Cluster

\begin{abstract}
The development of a region that continues to increase, both in terms of social and economic, attracts residents from other regions to have activities in the area. Regional development can be influenced by various factors, physical and non-physical factors. This study aimed to cluster the Greater Bandung area based on typology of regional development in each sub-district so that the planned development can be effective and efficient according to the conditions in each sub-district. This study used secondary data obtained from various institutions. Variables used in this study were the economic facilities availability index, social facilities availability index, educational facilities availability index, built up area
\end{abstract}


ratio, road density and population density with total 106 sub-districts. These datas were analyzed using the Modified Skalogram method, Principal Component Analysis and Spatial Clustering. The analysis showed that based on the typology of regional development, Greater Bandung can be grouped into 3 clusters, consisting of urban zone, suburban zone and rural zone. Urban zone consists of 34 sub-districts spreading mostly in Bandung City and Cimahi City. Suburban zone consists of 43 sub-districts spreading mostly in West Bandung Regency and Bandung Regency. Rural zone consists of 29 subdistricts spreading mostly in Sumedang Regency

Key words: facilities, built up area, regional development, Modified Skalogram, Spatial Clustering

\section{PENDAHULUAN}

Wilayah didefinisikan sebagai unit geografis dengan batas-batas wilayah tertentu dimana komponen di dalamnya memiliki keterkaitan dan hubungan fungsional antara satu wilayah dengan wilayah lainnya. Dari definisi tersebut terlihat bahwa tidak ada batasan spesifik akan luasan suatu wilayah. Wilayah tidak hanya merujuk pada tempat atau area melainkan kesatuan ekonomi, politik, sosial, administrasi, iklim hingga geografis sesuai dengan tujuan pembangunan atau kajian. Keragaman dalam mendefinisikan wilayah bergantung pada permasalahan atau tujuan pengembangan wilayah yang dihadapi (Rustiadi, Saefulhakim \& Panuju, 2009). Perkembangan suatu wilayah dipengaruhi oleh berbagai faktor diantaranya faktor geografis, jumlah sarana prasarana (Rustiadi et al., 2009), jumlah penduduk, jarak dengan pusat kota (Panuju \& Rustiadi, 2013), aksesibilitas yang memadai, iklim serta sumber daya alam yang melimpah (Lubis \& Sitorus, 2012). Selain itu jumlah dan jenis sarana di suatu wilayah pada umumnya berkorelasi erat dengan jumlah penduduk. Hal ini menyebabkan pada wilayah pusat dengan hirarki yang lebih tinggi seringkali memiliki kepadatan penduduk yang lebih tinggi dari hirarki yang lebih rendah (Rustiadi et al., 2009).

Pertumbuhan penduduk wilayah Bandung Raya yang terus meningkat berimplikasi pada peningkatan pembangunan wilayah yang kemudian menarik migran untuk datang dan beraktifitas di Bandung Raya. Fuadina (2018) mengemukakan bahwa dalam kurun waktu tahun 1983 - 2015 perubahan lahan di Bandung Raya menunjukkan luasan lahan terbangun dan kebun campuran yang terus meningkat setiap tahunnya dan dalam kurun waktu 2003 - 2014 terjadi peningkatan indeks perkembangan kecamatan yang ditandai dengan bertambahnya jumlah jenis fasilitas. Senada dengan hal ini, menurut Ardiwijaya, Sumardi, Suganda \& Temenggung (2015), jika peningkatan lahan terbangun ini dibiarkan maka diprediksi pada tahun 2051 ketersediaan lahan di Bandung Raya akan kurang dari 30\%. Hasil yang sama diperoleh oleh Noviyanti, Pravitasari \& Sahara (2020) yang menyatakan bahwa Wilayah Pengembangan KK Cekungan Bandung merupakan wilayah dengan tingkat lahan terbangun kedua tertinggi di Jawa Barat dan dalam rentang tahun 2010 - 2018 terus mengalami penurunan luas sawah akibat terdesak pembangunan lahan terbangun. Selain itu pada penelitian yang sama diperoleh hasil bahwa Kota Bandung dan Kota Cimahi memiliki persentase lahan terbangun lebih dari $42 \%$. Bahkan menurut Kustiawan \& Ladimananda (2012), diprediksi pada tahun 2020 wilayah Bandung Raya akan mencapai batas daya dukung untuk lahan terbangun.

Pengelompokkan tipologi wilayah berdasarkan karakteristik perkembangan wilayah dimaksudkan untuk mempermudah dalam menyusun perencanaan wilayah (Fafurida, 2012) sehingga pengembangan wilayah menjadi efektif dan efisien. Salah satu penelitian yang dilakukan oleh Budiyantini \& Pratiwi (2015) mengenai tipologi wilayah peri urban 
di Bandung Raya berdasarkan karakteristik fisik, sosial dan ekonomi mengelompokkan wilayah peri urban Bandung Raya menjadi tiga yaitu Predominantly Urban, Semi-Urban dan Potential Urban. Wilayah Predominantly Urban terdiri atas 57 Desa yang terletak di perbatasan Kabupaten Bandung dan memiliki karakteristik fisik, sosial dan ekonomi perkotaan yang signifikan. Wilayah Semi-Urban terdiri atas 123 Desa dan memiliki karakteristik campuran perkotaan dan perdesaan. Wilayah Potential Urban terdiri atas 75 Desa dan memiliki karakteristik perdesaan yang signifikan. Pada penelitian ini pengelompokkan wilayah Bandung Raya menggunakan metode spatial clustering dimana selain variabel karakteristik, variabel kedekatan wilayah juga menjadi pertimbangan dalam mengelompokkan wilayah. Hasil penelitian ini diharapkan dapat memberi masukan bagi perencanaan pembangunan di Bandung Raya. Sehingga rencana pembangunan tersebut dapat lebih efektif dan efisien sesuai dengan kondisi dan lokasi masing-masing kecamatan.

\section{METODE PENELITIAN}

\section{Analisis Tingkat Perkembangan Wilayah di Bandung Raya}

Penelitian ini menggunakan metode Skalogram Dimodifikasi untuk menganalisis tingkat perkembangan wilayah di Bandung Raya secara kuantitatif dengan mempertimbangkan keberadaan fasilitas pelayanan (Panuju \& Rustiadi, 2013; Utari, 2015), kapasitas serta akses berdasarkan jarak dan waktu tempuh menuju fasilitas tersebut (Panuju \& Rustiadi, 2013). Indeks perkembangan wilayah (IPK) dikelompokkan ke dalam tiga kelas hirarki, yaitu hiraki I, hirarki II dan hirarki III. Penentuan hirarki tersebut didasarkan pada nilai standar deviasi indeks perkembangan wilayah dan nilai rataannya sebagaimana terlihat pada Tabel 1.
Tabel 1. Penentuan nilai kelas hirarki

\begin{tabular}{lcc}
\hline No & Kelas & Nilai selang \\
\hline 1 & Hirarki I & IPK $>$ Rataan + St Dev IPK \\
2 & Hirarki II & Rataan $\leq$ IPK $\leq$ Rataan + St \\
& & Dev IPK \\
3 & Hirarki III & IPK $<$ Rataan \\
\hline
\end{tabular}

IPK = Indeks Perkembangan Kecamatan Sumber: Panuju \& Rustiadi, 2013

Data yang digunakan berdasarkan data potensi desa tahun 2018 bersumber dari Badan Pusat Statistik. Data potensi desa ini diagregasi menjadi kecamatan sehingga unit wilayah yang dianalisis pada penelitian ini adalah unit kecamatan di Bandung Raya. Data yang telah diagregasi tersebut kemudian dibedakan menjadi tiga jenis fasilitas dan dihitung menggunakan Microsoft Excel 2010. Fasilitas-fasilitas tersebut yaitu:

1. Data fasilitas ekonomi (jumlah kelompok pertokoan, pasar swalayan/minimarket, toko/warung kelontong, restoran/rumah makan, warung/kedai makanan minuman, hotel, hostel/motel/losmen, pasar permanen, pasar semi permanen, pasar tanpa bangunan, industri mikro kecil (IMK) kerajinan dari kulit, IMK kerajinan dari kayu, IMK kerajinan dari logam, IMK kerajinan anyaman/gerabah/keramik, IMK kerajinan dari kain/tenun, IMK kerajinan dari rotan/bambu/rumput/pandan, IMK makanan minuman, bank umum pemerintah, bank umum swasta, Bank Perkreditan Rakyat, supermarket/mal, SPBU).

2. Data fasilitas sosial (jumlah rumah sakit, rumah sakit bersalin, puskesmas dengan rawat inap, puskesmas tanpa rawat inap, poliklinik/balai pengobatan, tempat praktek dokter, tempat praktek bidan, posyandu, apotek, masjid, surau/langgar / musola, gereja kristen, gereja katolik, pura, wihara, keleteng).

3. Data fasilitas pendidikan (jumlah SD Negeri / sederajat, SD Swasta/sederajat, SMP Negeri /sederajat, SMP 
Swasta/sederajat,

SMA

Negeri/sederjat,

SMA

Swasta/sederajat, SMK Negeri, SMK

Swasta, Perguruan tinggi negeri, perguruan tinggi swasta).

Sehingga dari metode Skalogram

Dimodifikasi ini akan diperoleh:

1. Indeks ketersediaan fasilitas ekonomi

2. Indeks ketersediaan fasilitas sosial

3. Indeks ketersediaan fasilitas pendidikan

Kemudian ketiga variabel tersebut ditambahkan dengan tiga variabel lainnya yaitu:

1. Variabel rasio lahan terbangun yang dihasilkan dari overlay antara peta tutupan lahan tahun 2018 bersumber dari Bappeda Provinsi Jawa Barat dan peta administrasi wilayah Bandung Raya bersumber dari Badan Informasi Geospasial dengan menggunakan software Arcgis 10.2.

2. Variabel densitas jaringan jalan yang dihasilkan dari overlay antara peta jaringan jalan tahun 2018 bersumber dari Badan Informasi Geospasial dan peta administrasi wilayah Bandung Raya bersumber dari Badan Informasi Geospasial dengan menggunakan software Arcgis 10.2.

3. Variabel kepadatan penduduk tahun 2017 bersumber dari Badan Pusat Statistik.

\section{Principal Component Analysis}

Keenam variabel yang diperoleh selanjutnya akan dianalisis menggunakan Principal Component Analysis (PCA) untuk menghilangkan multikolinearitas sehingga akan diperoleh variabel yang saling bebas (Sriningsih, Haditja \& Prang, 2018). PCA dihitung dengan menggunakan software Statistica 8.0. Hasil dari PCA berupa factor score yang kemudian akan dianalisis kembali menggunakan metode Spatial Clustering dengan bantuan sofware Statistica 8.0, Microsoft Excel 2010 dan Arcgis 10.2 sehingga akan terbentuk pengelompokkan berdasarkan karakteristik dan kedekatan wilayah.

\section{Analisis Pengelompokan Tipologi Wilayah Kecamatan di Bandung Raya}

Analisis Spatial Clustering yang dilakukan dalam penelitian ini diawali dengan menentukan titik centroid $X$ dan titik centroid $Y$ dari setiap wilayah kecamatan di Bandung Raya. Titik centroid tersebut diperoleh dengan teknik calculate geometry dari peta administrasi wilayah Bandung Raya menggunakan software Arcgis 10.2. Kemudian menghitung nilai $X^{\prime}$ dan $Y^{\prime}$ yang merupakan standarisasi dari titik $X$ dan titik $Y$. Standarisasi ini dilakukan untuk menghilangkan satuan pada titik-titik tersebut. Selanjutnya menghitung bobot spasial $(\beta)$ yang ditetapkan sebesar $0.25,0.5$, 1,2 , dan 4. Hasil analisis menghasilkan anggota cluster dengan jarak yang diukur dari masing-masing pusat cluster. Menurut Rustiadi \& Kobayashi (2000), rumus jarak Euclidian dengan banyak variabel adalah sebagai berikut

$$
D_{i j}=\sqrt{\begin{array}{c}
\left(Z_{1 i}-Z_{1 j}\right)^{2}+\left(Z_{2 i}-Z_{2 j}\right)^{2} \\
+\beta\left\{\left(X_{i}{ }^{\prime}-X_{j}{ }^{\prime}\right)^{2}+\left(Y_{i}{ }^{\prime}-Y_{j}{ }^{\prime}\right)^{2}\right\}
\end{array}}
$$

dimana:

$D_{i j}=$ jarak euclidean berbobot spasial antara kecamatan $i$ dan $j$

$Z_{1 i}=$ nilai atribut kecamatan $i$ untuk factor score pertama hasil PCA

$Z_{1 j}=$ nilai atribut kecamatan $j$ untuk factor score pertama hasil PCA

$Z_{2 i}=$ nilai atribut kecamatan $i$ untuk factor score kedua hasil PCA

$Z_{2 j}=$ nilai atribut kecamatan $j$ untuk factor score kedua hasil PCA

$X_{i}{ }^{\prime}=$ nilai koordinat lokasi kecamatan $i$ pada sumbu $X^{\prime}$

$X_{j}^{\prime}=$ nilai koordinat lokasi kecamatan $j$ pada sumbu $X^{\prime}$

$Y_{i}^{\prime}=$ nilai koordinat lokasi kecamatan $i$ pada sumbu $Y^{\prime}$

$Y_{j}^{\prime}=$ nilai koordinat lokasi kecamatan $j$ pada sumbu $Y^{\prime}$

$\beta=$ bobot spasial $(0.25,0.5,1,2$ dan 4$)$

$i, j=$ kecamatan di Bandung Raya (106 kecamatan) 
Dalam analisis Spatial Clustering terdapat parameter lain yang diukur yaitu Coefficient of Variation (CV). CV adalah persentase keberagaman data dalam satu cluster yang sama. Semakin kecil nilai CV menunjukkan keragaman data dalam suatu cluster menjadi kecil. Hal tersebut menunjukkan bahwa $\mathrm{CV}$ yang rendah menjadi penciri suatu cluster yang baik (Wulandari, 2018). Menurut Rustiadi \& Kobayashi (2000), CV dirumuskan sebagai $C V=\sigma / \bar{x}$, dimana $\sigma=$ standar deviasi dari jarak $D_{i j}$ dan $\bar{x}=$ rata-rata jarak.

Selain itu DeMers (1997) dalam Rustiadi \& Kobayashi (2000) menggunakan angka contiguity (ketersambungan/K) sebagai ukuran tingkat kedekatan antar poligon dalam satu wilayah. Hal ini sesuai dengan penelitian Salazar, Velez, Parra \& Ortega (2002) yang menyatakan bahwa kriteria dalam memilih cluster yang optimal adalah compactness/contiguity, yaitu anggota dari masing-masing cluster harus sedekat mungkin dengan yang lain dan separation, yaitu antara satu cluster dengan cluster lainnya harus terpisah secara luas. Bobot spasial yang baik ditunjukan dengan wilayah yang compact, nilai $\mathrm{CV}$ dan nilai $\mathrm{K}$ yang kecil pada semua cluster. Hal ini dikarenakan $\mathrm{CV}$ yang kecil menandakan data dalam satu cluster semakin mirip, sedangkan K yang kecil menandakan cluster semakin rapat (compact). Kerangka berpikir penelitian secara lengkap disajikan pada Gambar 1.

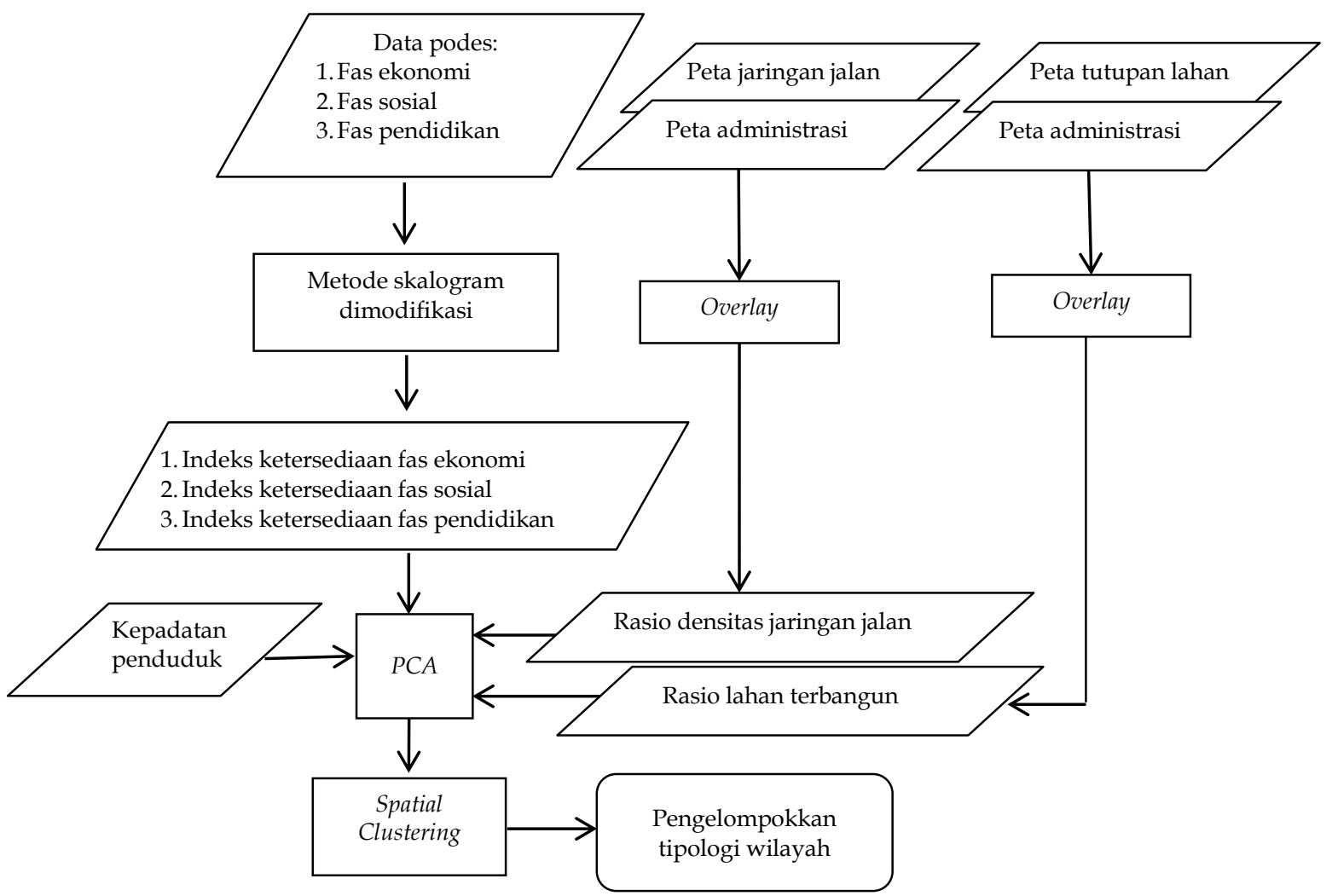

Gambar 1. Kerangka berpikir penelitian

\section{HASIL DAN PEMBAHASAN \\ Analisis Tingkat Perkembangan Wilayah di Bandung Raya}

Hasil analisis metode Skalogram Dimodifikasi disajikan pada Gambar 2. Dari Gambar 2 terlihat bahwa Kota Bandung mendominasi hirarki pertama (tertinggi) hampir di semua indeks ketersediaan fasilitas (IKF) diikuti oleh Kota Cimahi yang ditandai gradasi warna yang paling gelap. Dapat dikatakan bahwa Kota Bandung merupakan wilayah yang paling berkembang jika dibandingkan dengan kabupaten / kota lainnya di Bandung Raya. 
Hal ini dapat dipahami mengingat Kota Bandung merupakan ibukota provinsi Jawa Barat dan merupakan pusat dari metropolitan Bandung Raya sehingga memiliki fasilitas yang lebih banyak jenis dan jumlahnya. Sementara Kota Cimahi merupakan wilayah terdekat ke Kota Bandung.
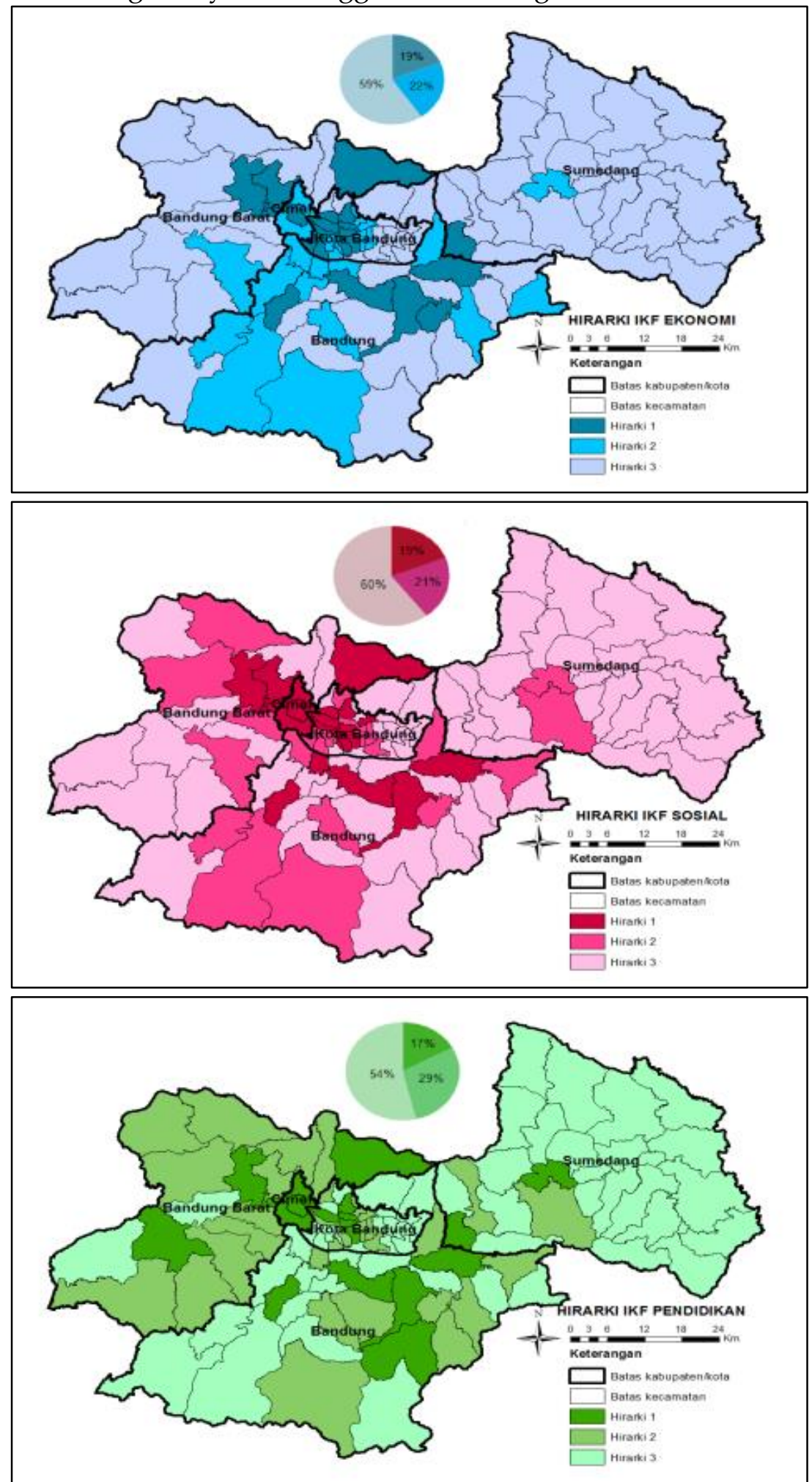

Gambar 2. Peta hirarki perkembangan wilayah di Bandung Raya berdasarkan: (a) indeks ketersediaan fasilitas (IKF) ekonomi, (b) indeks ketersediaan fasilitas (IKF) sosial dan (c) indeks ketersediaan fasilitas (IKF) pendidikan 


\section{Principal Component Analysis}

Hasil analisis PCA disajikan pada Tabel 2 dan Tabel 3. Berdasarkan nilai factor loading hasil PCA yang ditunjukan pada Tabel 2, dapat diketahui bahwa dari keenam variabel awal yang digunakan terbentuk dua faktor yang saling bebas. Faktor 1 dicirikan oleh tiga variabel yaitu variabel rasio lahan terbangun (BUILT_RASIO), densitas jaringan jalan (ROAD_DENS) dan kepadatan penduduk (POP_DENS). Faktor 2 dicirikan oleh variabel indeks ketersediaan fasilitas ekonomi (ECO_INDEX), fasilitas sosial (SOSIAL_INDEX) dan fasilitas pendidikan (EDU_INDEX). Dua faktor yang baru terbentuk ini menghasilkan variasi sebesar $88.89 \%$ sebagaimana terlihat pada Tabel 3, sehingga dapat dikatakan kedua faktor tersebut valid digunakan pada tahap analisis selanjutnya.

Tabel 2. Factor loadings hasil PCA

\begin{tabular}{lrr}
\hline & Factor 1 & Factor 2 \\
\hline ECO_INDEX & 0.37 & 0.84 \\
SOSIAL_INDEX & 0.39 & 0.86 \\
EDU_INDEX & 0.03 & 0.94 \\
BUILT_RASIO & 0.95 & 0.25 \\
ROAD_DENS & 0.90 & 0.23 \\
POP_DENS & 0.92 & 0.20 \\
\hline
\end{tabular}

Sumber: Hasil Penelitian, 2019

Tabel 3. Eigenvalues Hasil PCA

\begin{tabular}{ccccc}
\hline & $\begin{array}{c}\text { Eigen } \\
\text { value }\end{array}$ & $\begin{array}{c}\text { \% Total } \\
\text { variance }\end{array}$ & $\begin{array}{c}\text { Cumulative } \\
\text { Eigenvalue }\end{array}$ & $\begin{array}{c}\text { Cumulative } \\
\%\end{array}$ \\
\hline 1 & 3.98 & 66.35 & 3.98 & 66.35 \\
2 & 1.35 & 22.54 & 5.33 & 88.89 \\
\hline
\end{tabular}

Sumber: Hasil Penelitian, 2019

\section{Analisis Pengelompokan Tipologi Wilayah Kecamatan di Bandung Raya}

Hasil dendogram dari factor score PCA sebagaimana disajikan pada Gambar 3 menunjukkan bahwa jumlah cluster yang optimal untuk wilayah Bandung Raya adalah 3 cluster sesuai dengan jarak terjauh.
Tree Diagram for 106 Cases

Ward's method

Euclidean distances

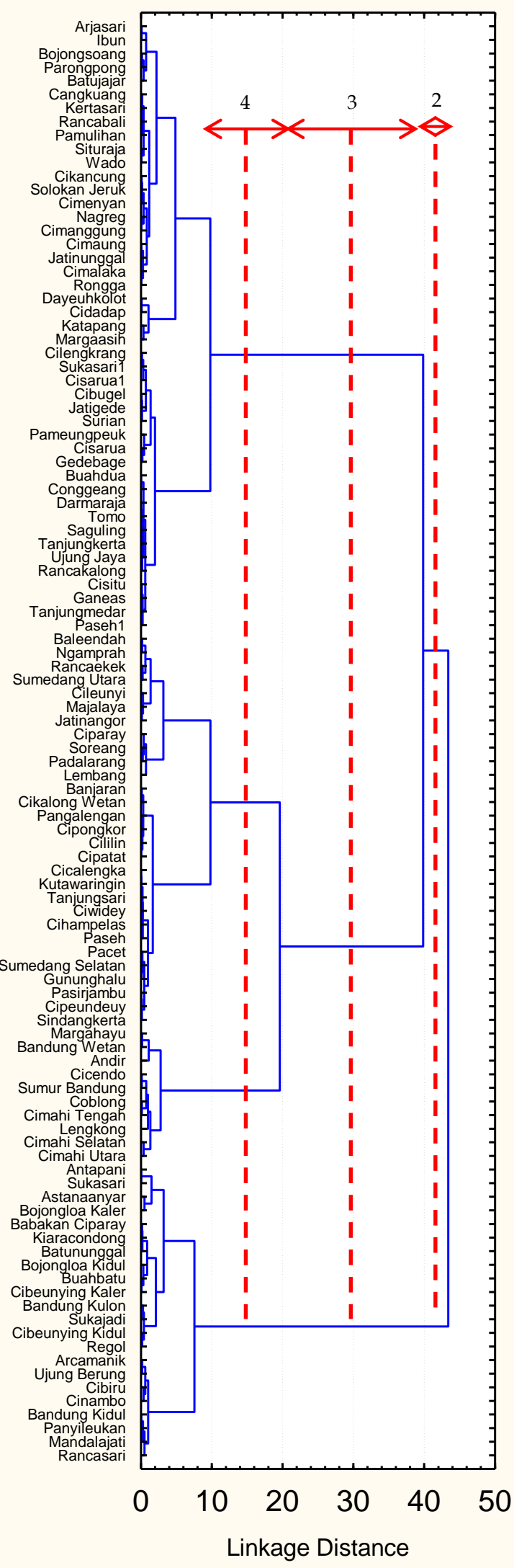

Gambar 3. Dendogram pada data hasil PCA 
Sementara Gambar 4 menunjukkan grafik nilai rata-rata (graph of means)dari setiap variabel yang digunakan sesuai dengan masing-masing cluster tanpa bobot spasial, dengan bobot spasial 0.25 , bobot spasial 0.5 , bobot spasial 1, bobot spasial 2 dan bobot spasial 4. Dari Gambar 4 (a) terlihat bahwa apabila kecamatan di Bandung Raya dibuat menjadi 3 cluster tanpa bobot spasial, maka pengelompokan terbagi menjadi wilayah dengan ciri perkotaan, suburban dan perdesaan. Cluster perkotaan ditunjukan dengan warna hijau dimana faktor 1 (rasio lahan terbangun, densitas jaringan jalan dan kepadatan penduduk) lebih dominan dari cluster lainnya. Hal ini disebabkan daerah perkotaan umumnya memiliki pembangunan yang pesat, seiring dengan pertambahan penduduk dari dalam wilayah serta penduduk dari daerah lain yang kemudian menetap di perkotaan. Cluster suburban ditunjukan dengan warna biru dimana faktor 2 (indeks ketersediaan fasilitas ekonomi, sosial dan pendidikan) tinggi namun faktor 1 (indeks perkembangan wilayah, rasio lahan terbangun dan kepadatan penduduk) sedang. Hal ini disebabkan daerah suburban merupakan wilayah perdesaan dengan ciri menyerupai perkotaan dari segi fasilitas sehingga indeks ketersediaan fasilitas tinggi namun masih terdapat lahan sawah dan pembangunan belum sepesat daerah perkotaan.

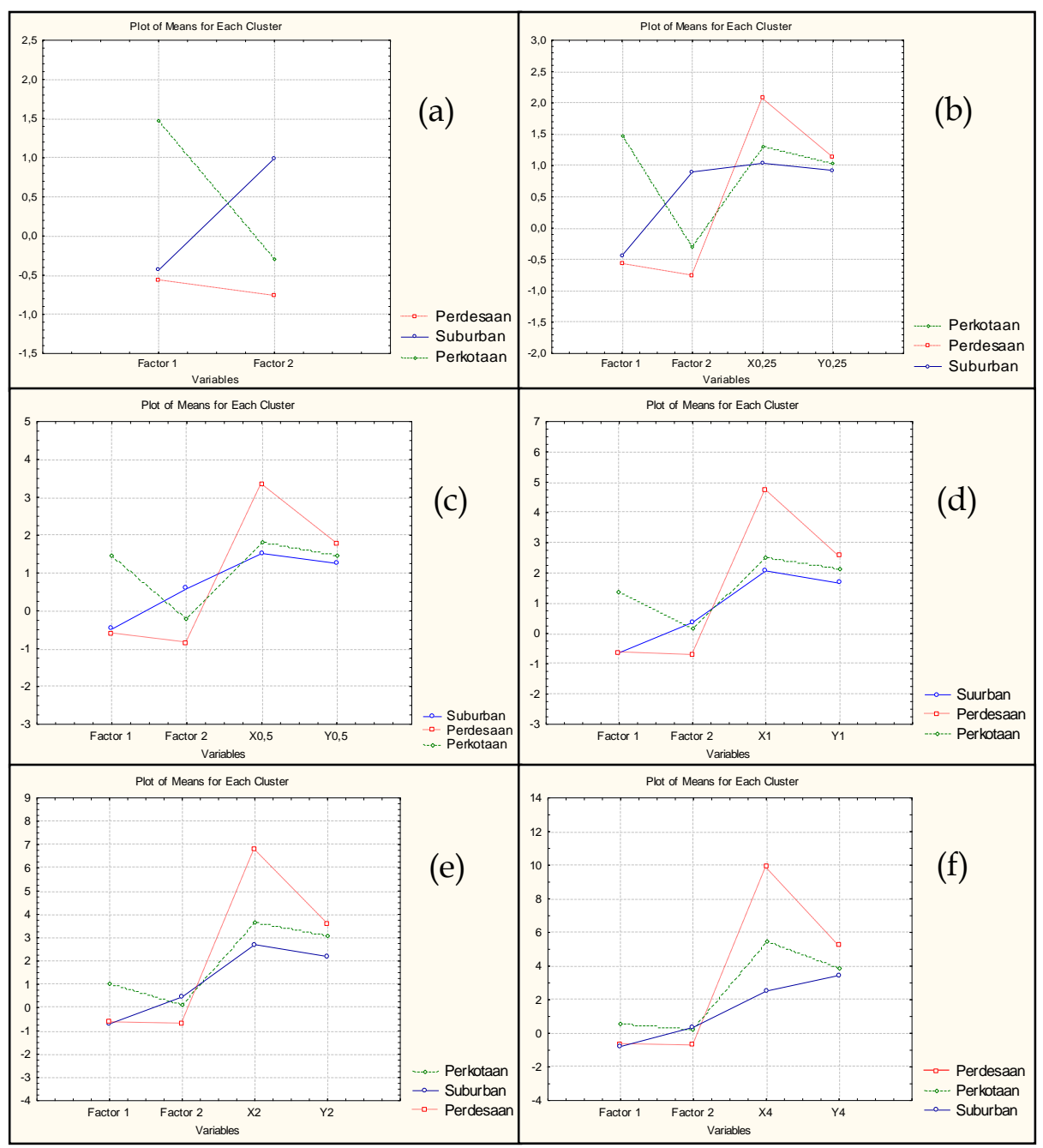

Gambar 4. Grafik nilai rata-rata variabel hasil analisis cluster di wilayah Bandung Raya: (a) tanpa bobot spasial, (b) bobot spasial 0.25, (c) bobot spasial 0.5, (d) bobot spasial 1, (e) bobot spasial 2 dan (f) bobot spasial 4 
Cluster perdesaan ditunjukan dengan warna merah dimana faktor 1 dan faktor 2 lebih rendah dari cluster lainnya. Hal ini menunjukkan baik dari segi jumlah fasilitas maupun pembangunan, cluster perdesaan masih lebih rendah dibandingkan cluster suburban dan perkotaan. Pada Gambar 4 (b) hingga Gambar 4 (f) menunjukan grafik dengan penambahan bobot dimana terlihat bahwa semakin besar bobot yang digunakan maka pengelompokkan wilayah lebih terfokus pada kedekatan atau lokasi wilayah, tidak pada variabel atau karakteristik wilayah yang digunakan. Hasil cluster ditampilkan dalam bentuk peta pada Gambar 5. Membandingkan keenam gambar pada Gambar 5 dapat disimpulkan semakin besar bobot yang digunakan maka hasil peta akan semakin compact. Pada Gambar 5 (a), hasil pengelompokkan wilayah masih terlihat menyebar atau acak sehingga akan menyulitkan dalam pengembangan wilayah. Begitu pula dengan Gambar 5 (b), Gambar 5 (c) dan Gambar 5 (e). Pada Gambar 5 (d) dan Gambar 5 (f) terlihat peta memiliki nilai $\mathrm{K}$ sama dengan 1 dan hasil pengelompokkan wilayah yang compact dibandingkan dengan gambar lainnya. Namun jika dilihat dari nilai CV, Gambar 5 (d) memiliki nilai CV yang relatif lebih kecil dari bobot lainnya. Selain itu jika dilihat dari Gambar 4 (f) terlihat pengelompokan wilayah dengan bobot spasial 4 menyebabkan variabel yang digunakan menjadi berhimpitan dan mirip satu sama lainnya. Sehingga bobot spasial 1 ditetapkan sebagai bobot spasial terbaik dalam mengelompokkan wilayah kecamatan di Bandung Raya.Pada Gambar 5 (d) terlihat bahwa wilayah bercirikan perkotaan meliputi Kota Bandung kecuali Kecamatan Gedebage, seluruh Kota Cimahi dan dua kecamatan di Kabupaten Bandung yang berbatasan dengan Kota Bandung. Hal ini disebabkan potensi ekonomi yang dimiliki wilayah tersebut didominasi industri dan perdagangan (BPS Provinsi Jawa Barat, 2018) sehingga secara tidak langsung meningkatkan pembangunan fasilitas dan aksesibilitas dari dan menuju daerah tersebut. Hal ini tentunya akan meningkatkan pembangunan secara fisik, perkembangan wilayah serta menarik penduduk untuk menetap di wilayah tersebut. Wilayah bercirikan daerah suburban pada Gambar 5 (d) meliputi Kabupaten Bandung dan Kabupaten Bandung Barat. Hal ini kemungkinan disebabkan oleh potensi pariwisata yang dimiliki kedua wilayah tersebut sehingga memiliki fasilitas penunjang yang lebih banyak dari daerah perdesaan meskipun dari segi luasan lahan terbangun, densitas jaringan jalan dan kepadatan penduduk masih lebih rendah dari daerah perkotaan. Wilayah bercirikan perdesaan pada Gambar 5 (d) meliputi Kabupaten Sumedang. Hal ini disebabkan sektor pertanian di Kabupaten Sumedang masih mendominasi perekonomian dengan menjadi penyumbang PDRB terbesar (BPS Kabupaten Sumedang, 2018), sehingga dari segi pembangunan fisik, fasilitas, aksesibilitas dan kepadatan penduduk lebih rendah dari suburban dan perkotaan. Anggota dari masing-masing cluster pada pengelompokan tipologi kecamatan di Bandung Raya berdasarkan analisis Spatial Clustering dengan bobot spasial 1 disajikan pada Tabel 4. 


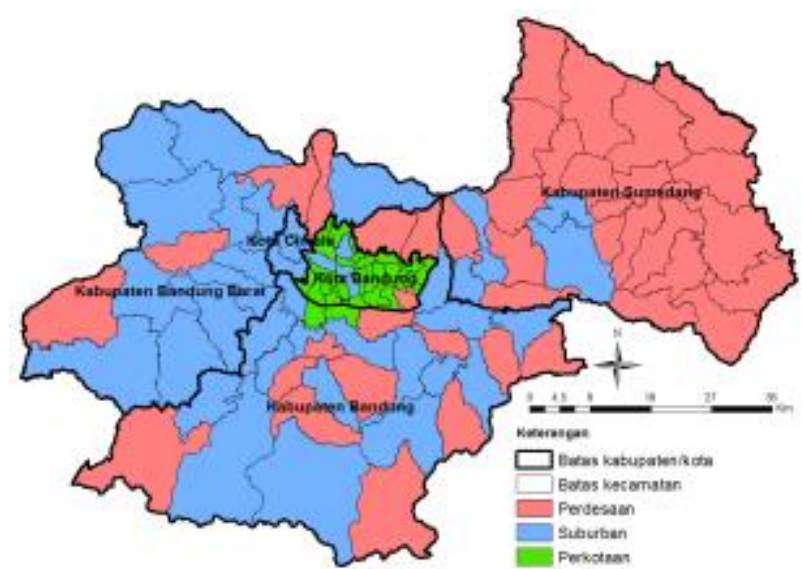

(a)

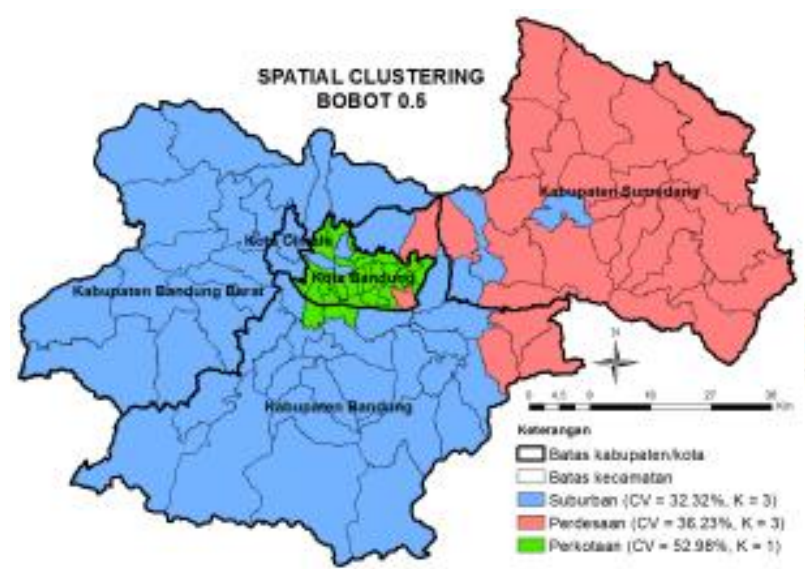

(c)

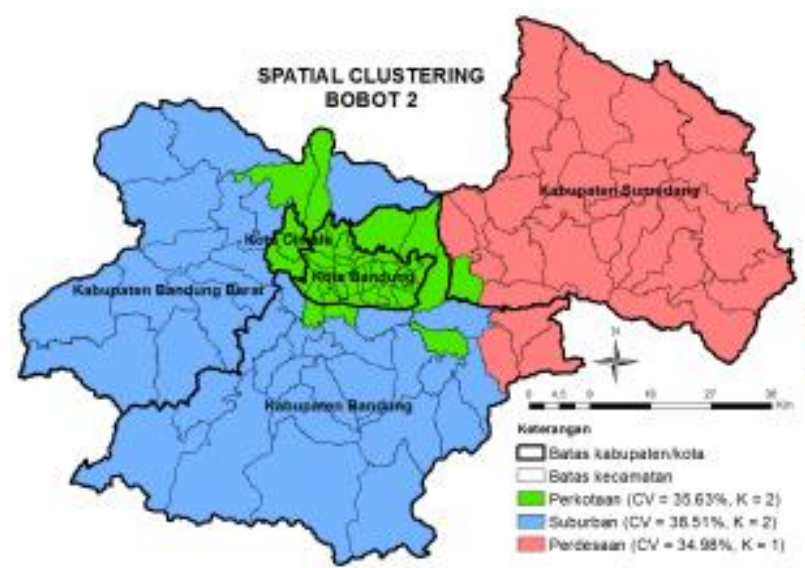

(e)

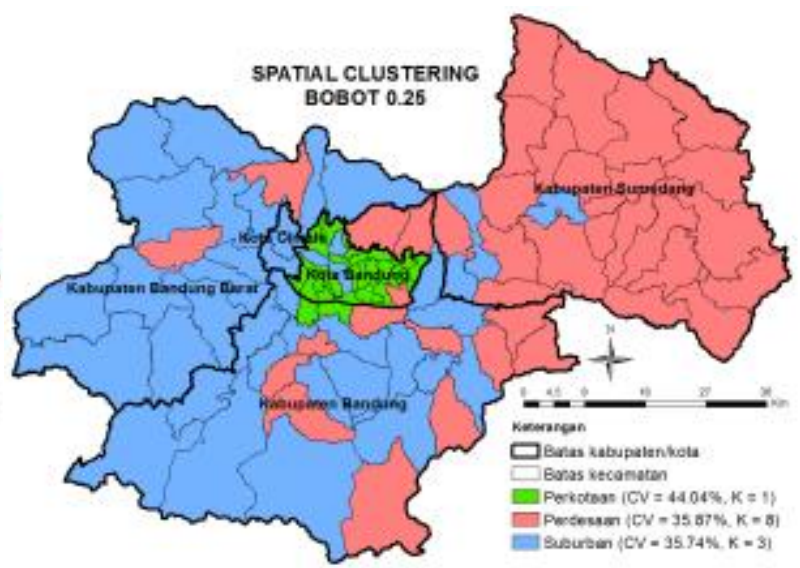

(b)

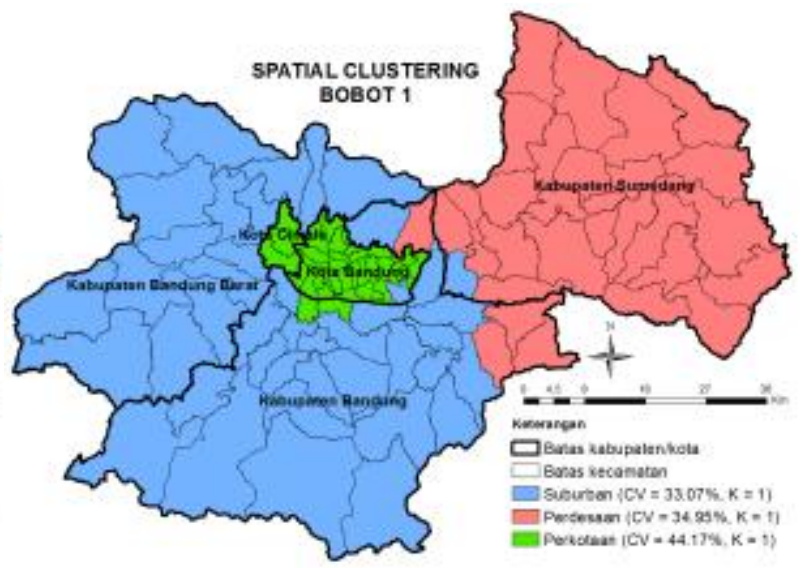

(d)

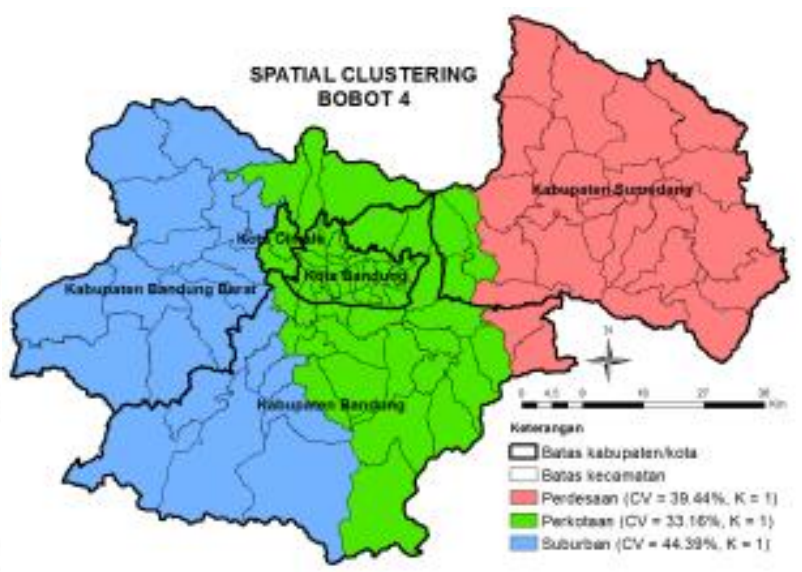

(f)

Gambar 5. Peta tipologi kecamatan di Bandung Raya berdasarkan pengelompokan 3 jenis cluster: (a) tanpa bobot spasial, (b) bobot spasial 0.25, (c) bobot spasial 0.5, (c) bobot spasial 1, (e) bobot spasial 2 dan (f) bobot spasial 4 
Tabel 4. Anggota dari masing-masing cluster pada pengelompokkan tipologi kecamatan di Bandung Raya berdasarkan analisis Spatial Clustering dengan bobot spasial 1

\begin{tabular}{|c|c|}
\hline Cluster & Nama Kecamatan \\
\hline Perdesaan & $\begin{array}{l}\text { Kabupaten Bandung: } \\
\text { Cicalengka, Cikancung, Cilengkrang, Nagreg } \\
\text { Kabupaten Sumedang: } \\
\text { Buahdua, Cibugel, Cimalaka, Cimanggung, Cisarua, Cisitu, Conggeang, Darmaraja, } \\
\text { Ganeas, Jatigede, Jatinunggal, Pamulihan, Paseh, Rancakalong, Situraja, Sukasari, } \\
\text { Sumedang Selatan, Sumedang Utara, Surian, Tanjungkerta, Tanjungmedar, } \\
\text { Tanjungsari, Tomo, Ujung Jaya, Wado }\end{array}$ \\
\hline Suburban & $\begin{array}{l}\text { Kabupaten Bandung: } \\
\text { Arjasari, Baleendah, Banjaran, Bojongsoang, Cangkuang, Cileunyi, Cimaung, } \\
\text { Cimenyan, Ciparay, Ciwidey, Ibun, Katapang, Kertasari, Kutawaringin, Majalaya, } \\
\text { Margaasih, Pacet, Pameungpeuk, Pangalengan, Paseh, Pasirjambu, Rancabali, } \\
\text { Rancaekek, Solokan Jeruk, Soreang } \\
\text { Kabupaten Sumedang: } \\
\text { Jatinagor } \\
\text { Kabupaten Bandung Barat: } \\
\text { Batujajar, Cihampelas, Cikalong Wetan, Cililin, Cipatat, Cipeundeuy, Cipongkor, } \\
\text { Cisarua, Gununghalu, Lembang, Ngamprah, Padalarang, Parongpong, Rongga, } \\
\text { Saguling, Sindangkerta } \\
\text { Kota Bandung: } \\
\text { Gedebage }\end{array}$ \\
\hline Perkotaan & $\begin{array}{l}\text { Kabupaten Bandung: } \\
\text { Dayeuhkolot, Margahayu } \\
\text { Kota Bandung: } \\
\text { Andir, Antapani, Arcamanik, Astanaanyar, Babakan Ciparay, Bandung Kidul, Bandung } \\
\text { Kulon, Bandung Wetan, Batununggal, Bojongloa Kaler, Bojongloa Kidul, Buahbatu, } \\
\text { Cibeunying Kaler, Cibeunying Kidul, Cibiru, Cicendo, Cidadap, Cinambo, Coblong, } \\
\text { Kiaracondong, Lengkong, Mandalajati, Panyileukan, Rancasari, Regol, Sukajadi, } \\
\text { Sukasari, Sumur Bandung, Ujung Berung } \\
\text { Kota Cimahi: } \\
\text { Cimahi Selatan, Cimahi Tengah, Cimahi Utara }\end{array}$ \\
\hline
\end{tabular}

\section{KESIMPULAN}

Penggunaan analisis Spatial

Clustering dengan bobot spasial 1
merupakan bobot terbaik untuk mengelompokkan wilayah Bandung Raya karena cluster yang dihasilkan lebih compact sehingga diharapkan pembangunan wilayah yang direncanakan lebih efektif dan efisien sesuai dengan karakteristik masingmasing kecamatan. Berdasarkan tipologi perkembangan wilayah dengan analisis Spatial Clustering, wilayah Bandung Raya dapat dibedakan menjadi 3 cluster yakni wilayah perkotaan yang terdiri atas 34 kecamatan mayoritas di Kota Bandung dan Kota Cimahi, wilayah suburban yang terdiri atas 43 kecamatan mayoritas di Kabupaten Bandung dan Kabupaten Bandung Barat serta wilayah perdesaan yang terdiri atas 29 kecamatan mayoritas di Kabupaten Sumedang.

\section{UCAPAN TERIMA KASIH}

Ucapan terimakasih penulis haturkan kepada BPS RI, BPS Provinsi Jawa Barat, Bappeda Provinsi Jawa Barat dan Badan Informasi Geospasial yang telah memberikan kemudahan akses data pada penelitian ini. Ucapan terimakasih juga penulis haturkan kepada Pusbindiklatren Bappenas atas dana penelitian yang telah diberikan.

\section{DAFTAR PUSTAKA}

Ardiwijaya, V.S., Sumardi, T.P., Suganda, E \& Temenggung, Y.A. (2015). Rejuvenating Idle Land to Sustainable 
Urban Form: Case Study of Bandung Metropolitan Area, Indonesia. Procedia Environmental Sciences, 28, 176-184.

Badan Pusat Statistik Kabupaten Sumedang. (2018). Kabupaten Sumedang Dalam Angka 2018. BPS Kabupaten Sumedang. Sumedang.

Badan Pusat Statistik Provinsi Jawa Barat. (2018). Provinsi Jawa Barat Dalam Angka 2018. BPS Provinsi Jawa Barat. Bandung.

Budiyantini, Y., Pratiwi, V. (2015). Peri-urban Typologi of Bandung Metropolitan Area. Procedia Social and Behavioral Sciences, 833-837.

Fafurida. (2012). Analysis of Inter Sectoral Linkages in Semarang Regency. Economic Journal of Emerging Markets, 4(1), 15-24.

Fuadina, L.N. (2018). Perubahan Penggunaan Lahan dan Keragaman Spasial FaktorFaktor yang Mempengaruhi Pertumbuhan Perkotaan di Metropolitan Bandung. Tesis Sekolah Pascasarjana Institut Pertanian Bogor. Bogor. 72 hlm.

Kustiawan, I., \& Ladimananda, A. (2012). Pemodelan Dinamika Perkembangan Perkotaan dan Daya Dukung Lahan di Kawasan Cekungan Bandung. Tata Loka, 14(2), 98-112.

Lubis, D.P., \& Sitorus, N. (2012). Analisis Spasial yang Mempengaruhi Perkembangan Kecamatan Ujung Pandang Kabupaten Simalungun Tahun 2005 - 2010. Jurnal Geografi, 4(2), 1-14.

Noviyanti, D., Pravitasari, A.E., \& Sahara, S. (2020). Analisis Perkembangan Wilayah Provinsi Jawa Barat untuk Arahan Pembangunan Berbasis Wilayah Pengembangan. Jurnal Geografi, 12(1), 280-296.

Panuju, D.R., \& Rustiadi, E. (2013). Teknik Analisis Perencanaan dan Pengembangan Wilayah. Institut Pertanian Bogor. Bogor.

Rustiadi, E., \& Kobayashi, S. (2000). Contiguous Spatial Classification: A New Approach on Quantitative Zoning Method.
Journal of Geography Education, 43, 122136.

Rustiadi, E., Saefulhakim, S., \& Panuju, D.R. (2009). Perencanaan dan Pengembangan Wilayah. Crespent Press \& Yayasan Obor Indonesia. Bogor.

Salazar, E.J., Velez, A.C., Parra, C.M., \& Ortega, O. (2002). A Cluster Validity Index for Comparing Non-Hierarchical Clustering Methods. EITI, 1-5.

Sriningsih, M., Hatidja, D., \& Prang, J.D. (2018). Penanganan Multikolinearitas dengan Menggunakan Analisis Regresi Komponen Utama pada Kasus Impor Beras di Provinsi Sulut. Jurnal Ilmiah Sains, 18(1), 18-24.

Utari MGES. (2015). Analisis Sistem Pusat Pelayanan Permukiman di Kota Yogyakarta Tahun 2014. Journal of Economics and Policy, 8(1), 62-72.

Wulandari, S. (2018). Pola Spasial Inkonsistensi Pemanfaatan Ruang dengan Keterkaitan Status KepemilikanPenguasaan Lahannya di Sub DAS Ciliwung Hulu. Tesis Sekolah Pascasarjana Institut Pertanian Bogor. Bogor. $81 \mathrm{hlm}$. 